Comp. Biochem. Physiol. Vol. 114C, No. 1, pp. 51-55, 1996

Copyright 1996 Elsevier Science Inc.

ISSN 0742-8413/96/\$15.00

SSDI $0742-8413(95) 02104-3$

\title{
Proteins and Esterase Isozymes During Developmental Stages of Organophosphate Resistant Strains in Anopheles stephensi Liston
}

\author{
D. E. Gangadhar Rao and N. J. Shetty \\ Centre for Applied Genetics, Bangalore University, Bangalore 560 056, India.
}

\begin{abstract}
The proteins and esterase isozymes from Anopheles stephensi were analysed by polyacrylamide gel electrophoresis. Changes in proteins and esterase isozyme patterns during developmental stages were studied. A few specific protein bands were present especially in the third instar larval stage. In most strains, eggs showed only one esterase band. During the larval development many bands were gradually formed and most anodal bands were lost upon pupation. The adults showed differences in intensity and mobility exhibiting sexual dimorphism. The protein and esterase isozyme patterns of organophosphate (fenthion, methyl parathion and malathion) resistant and susceptible strains during developmental stages were compared. The zymogram and relative mobility showed variation in the number of intensity of proteins and esterase bands in the resistant strains as compared to the susceptible strains. Сомр вIOCHEM PHYsIOL 114C, 51-55, 1996.
\end{abstract}

KEY WORDS. Anopheles stephensi, organophosphate resistance, electrophoresis, proteins, esterase isozymes

\section{INTRODUCTION}

Though mosquitoes have developed resistance for various types of insecticides, organophosphate (OP) chemicals such as fenthion, methyl parathion, and malathion are still being used for control of malaria vectors, including Anopheles stephensi. The development of OP-insecticide resistance in An. stephensi has been reported (17,21). Little information is available on electrophoretic changes of protein patrern in mosquitoes $(15,16)$. The electrophoretic analysis of esterases in relation to OP-insecticide resistance have been reported in a few species of mosquitoes $(7,8,9,11,14)$. However, the studies are too preliminary on differences in protein and esterase isozymes associated with insecticide resistance in An. stephensi.

The present investigation deals with the changes in protein and esterase isozyme patterns during developmental stages of fenthion, methyl parathion and malathion resistant and susceptible strains of An. stephensi, by using polyacrylamide gel electrophoresis.

\section{MATERIAL AND METHODS}

Several laboratory strains of An. stephensi were used in the experiments (Table 1). The mosquitoes were cultured under controlled conditions at $25^{\circ} \mathrm{C}$ and $80 \%$ humidity. The females were blood fed on mice. The larval resistance/suscep-

Address reprint requests to: N.J. Shetty, Center for Applied Genetics, Bangalore University, Jnana Bharathi, Bangalore 560056 India.

Received 2 July 1994; revised 7 July 1995; accepred 27 November 1995. tibility tests were carried out and the $\mathrm{LC}_{50}$ values were determined (20).

The material used for electrophoretic study of protein and esterase isozymes were eggs, individual third instar larva, pupa, freshly emerged adult male and female of an isofemale of each of the resistant (FR, PR, and MR) and susceptible ( $\mathrm{fs}, \mathrm{ps}$, and $\mathrm{ms}$ ) strains. Individual pupae of each strain were isolated in test tubes and sex was determined after adults emerged.

The material (in three replicates) was homogenised in $0.5 \mathrm{ml}$ of $0.06 \mathrm{M}$ Tris- $\mathrm{HCl}, \mathrm{pH} 6.8$ and centrifuged at 10,000 rpm for $10 \mathrm{~min}$. The supernatant was estimated for each sample according to the method of Lowry et al. (10) and the concentration of protein was adjusted to give $1 \mathrm{mg} / \mathrm{ml}$. $50 \mu 1$ of the extract of each sample (in three replicates) was used for electrophoretic study of proteins and esterases using polyacrylamide gels $(1,19)$. The reagents for preparation of gels were of analytical grade. The gels were casted in the form of slabs of $1.5 \mathrm{~mm}$ thick using glass plates measuring $18 \times 16 \mathrm{cms}$. The separating gel consisted of $7.5 \%$ (Acrylamide + Bisacrylamide) and 0.04M Tris-HCl, $\mathrm{pl}$ 8.8. The stacking gel was of $3 \%$ (Acrylamide + Bisacrylamide) and 0.01M Tris- $\mathrm{HCl}, \mathrm{pH} 6.8$. Ammonium per sulphate (APS) was used as polymerizing agent in final concentration of $0.1 \%$ along with $0.01 \% \mathrm{~N}, \mathrm{~N}, \mathrm{~N}, \mathrm{~N}$-Tetramethylethylenediamine (TEMED) as the catalyst. Electrophoresis was subjected in cold at $100 \mathrm{~V}$ in the stacking gel and $200 \mathrm{~V}$ in the separating gel, using $0.025 \mathrm{M}$ Tris-glycine buffer ( $\mathrm{pH}$ 8.3) as tank buffer.

The gels were stained for proteins with $0.1 \%$ Commassie 
TABLE 1. An. stephensi strains used: in the experiments.

\begin{tabular}{|c|c|c|c|}
\hline \multicolumn{4}{|c|}{ Organophosphate susceptible strains } \\
\hline Strain & Originally collected place & Year & $\begin{array}{l}\mathrm{LC}_{50} \\
\text { (insecticide) }\end{array}$ \\
\hline fs & WG, Bangalore, India & 1984 & $\begin{array}{l}0.003 \text { ppm (fen- } \\
\text { thion) }\end{array}$ \\
\hline ps & KOR, Bangalore, India & 1984 & $\begin{array}{l}0.06 \mathrm{ppm} \text { (methyl } \\
\text { parathion }\end{array}$ \\
\hline $\mathrm{ms}$ & MSN, Bangalore, India & 1984 & $\begin{array}{l}0.15 \mathrm{ppm} \text { (mala- } \\
\text { thion) }\end{array}$ \\
\hline \multicolumn{4}{|c|}{ Organophosphate resistant strains } \\
\hline Strain & Originally collected place & Year & $\begin{array}{l}\mathrm{LC}_{50} \\
\text { (insecticide) }\end{array}$ \\
\hline FR & WG, Bangalore, India & 1989 & $\begin{array}{l}0.5 \mathrm{ppm} \text { (fen- } \\
\text { thion) }\end{array}$ \\
\hline PR & KOR, Bangalore, India & 1989 & $\begin{array}{l}1.4 \mathrm{ppm} \text { (methyl } \\
\text { parathion) }\end{array}$ \\
\hline MR & MSN, Bangalore, India & 1989 & $\begin{array}{l}9.33 \mathrm{ppm} \text { (mala- } \\
\text { thion) }\end{array}$ \\
\hline
\end{tabular}

Strains: $f \mathrm{~s}=$ fenthion susceptible, $\mathrm{ms}=$ malathion susceptible, $\mathrm{ps}=$ methyl parathion susceptible, $\mathrm{PR}=$ methyl parathion resistant, $\mathrm{FR}=$ fenthion resistant, $M R=$ malathion resistant.

Blue, dissolved in 10\% acetic acid and $20 \%$ ethanol, for overnight. For staining the nonspecific esterases, the gels were incubated for $10 \mathrm{~min}$ in $0.1 \mathrm{M}$ Sodium phosphate buffer (pH 7.0). The staining solution consisted of $20 \mathrm{mg}$ alphanaphthyl acetate and $40 \mathrm{mg}$ Fast Blue-RR (4-Benzoylamino-2,5-Dimethoxy-aniline) in $100 \mathrm{ml}$ of sodium phosphateibuffer ( $\mathrm{pH} 7.0)$. The gels were destained in $10 \%$ acetic acid. The relative mobility $(\mathrm{Rm})$ for proteins and esterase bands with reference to known indicator dye were calculated using the formula: Distance moved by the band/ Distance moved by the marker dye.

\section{RESULTS}

The total protein content during each developmental stage of resistant (FR, PR, and MK) and susceptible ( $\mathrm{ts}$, ps, and ms) strains are presented in Fig. 1. The protein content was found to be similar in fs, ps, and ms strains. Therefore, all these three strains were represented by a single susceptible "control." The protein content in resistant strains was found to be higher when compared to "control." The FR strain showed an increase of $33.80,24.40,13.14,37.57$, and $24.99 \%$; in protein content for eggs, larvae, pupae, adult males and females respectively, when compared to "control." Similarly, the PR strain showed an increase of 36.14 , 20.67, 15.91, 33.26, and 21.22; whereas MR strain showed a minimum increase of $8.97,7.06,4.88,7.54$, and $1.66 \%$ for the above stages respectively.

The $\mathrm{fs}$, ps, and ms strains showed similar protein bands and represented by a single susceptible "control." The changes in protein pattern at different stages of develop-

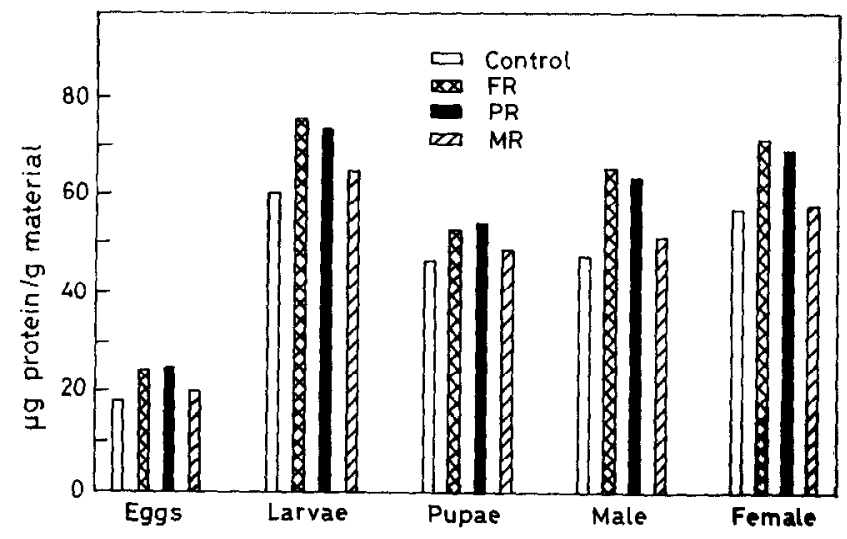

FIG. 1. Histogram showing quantitative changes of proteins during developmental stages of control (susceptible) and resistant strains for fenthion (FR), methyl parathion (PR) and malathion (MR) in An. stephensi.

ment in resistant (FR, $P R$, and $M R$ ) strains and control are computed in Fig. 2. Some of the protein bands were common among the control and the resistant strains which include six in eggs $(2,5,6,7,8$, and 12$)$; one in larvae (15); five in pupae $(4,5,10,14$, and 17$)$; six in males $(3,5,6,11,14$, and 17) and seven in females $(2,7,9,11,14,16$, and 17). Each resistant strain was characterised by a few specific bands especially in the larval stages. These bands include three $(1,7$, and 17) in FR strain; six $(1,7,9,10,12$, and 17) in PR strain and five $(2,4,7,8$, and 16$)$ in MR strain, which were not observed in the control. There was no significant difference among the eggs, pupae and adult stages of the FR, PR, and MR strains.

The nonspecific esterase isozyme patterns at different stages of development in resistant (FR, PR, and MR) strains and control are computed in Fig. 3 . The fs, ps, and ms strains showed similar esterase bands and represented by a single susceptible "control." Some of the esterase bands were common in the control and resistant strains which include one in eggs (Est-5); two in larvae (Est-8 and 11); three in pupae (Est-2, 16, and 17); one in males (Est-9) and two in females (Est-4 and 14).

Several larval specific esterase bands in resistant strains include five (Est-2, 6, 7, 13, and 14) in both FR and PR strains, whereas only one (Est-9) in the MR strain, when compared to the control. On the contrary, Est-10 in larvae; Est-12 in pupae and two (Est-2 and 16) in both males and females which was observed in the control were not expressed in the FR, $P R$, and MR strains, presumably hydrolysed by the OP-insecticides.

The zymograms and relative mobility $(\mathrm{Rm})$ values of proteins and esterase isozymes during developmental stages for FR, PR, and MR strains of An. stephensi are presented in Fig. 4. The $R_{m}$ values showed variation in the 19 protein bands which ranged from 0.04 to 0.96 . Similarly, the 17 esterase bands showed $R_{m}$ values from 0.18 to 0.78 . How- 


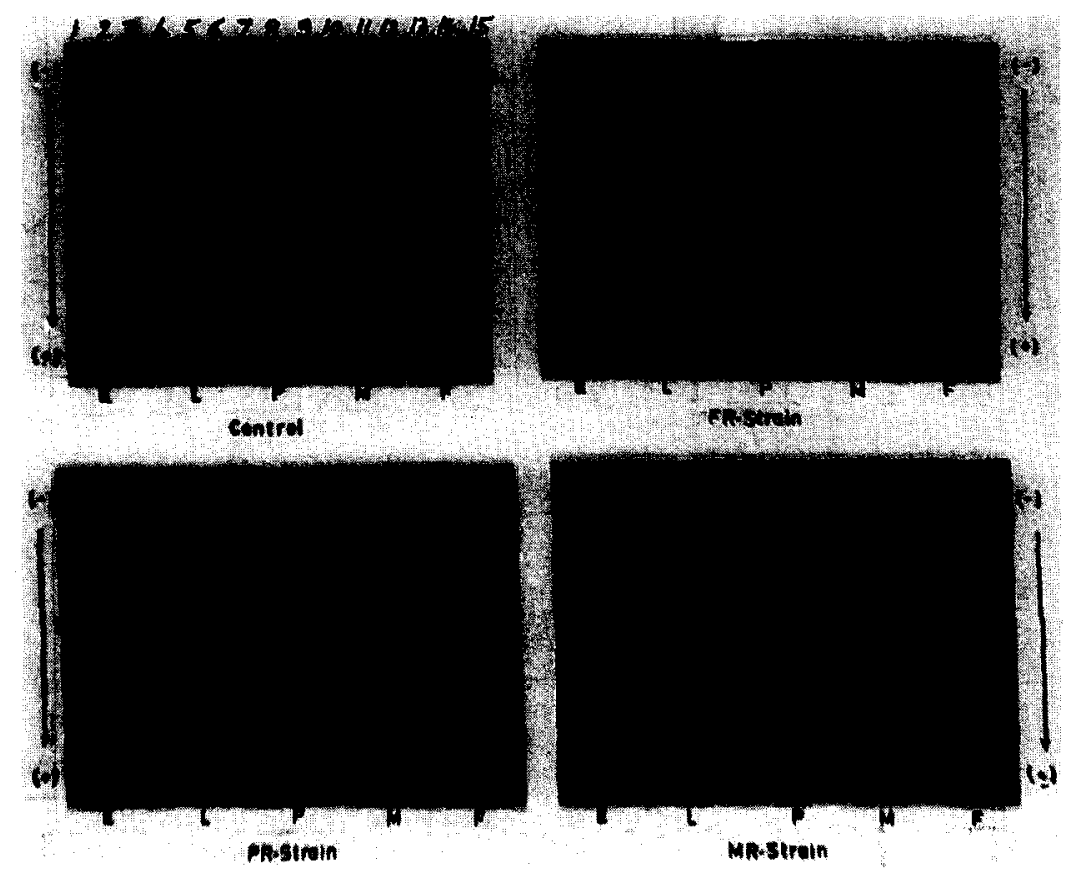

FIG. 2. Protein pattern during different developmental stages for control (susceptible) and resistant strains for fenthion (FR), methyl parathion (PR) and malathion $(\mathrm{MR})$ in $A n$. stephensi. Life cycle stages: $E=$ eggs (channel $1-3$ ), $L=$ individual third instar larva (channel 4-6), $P=$ individual pupa (channel 7-9), $M=$ individual adult male (channel 10-12) and $F=$ individual adult female (channel 13-15). In resistant strains, eggs showed maximum protein bands few specific larval bands most anodal bands disappear upon pupation and certain bands reappear during adult stage.

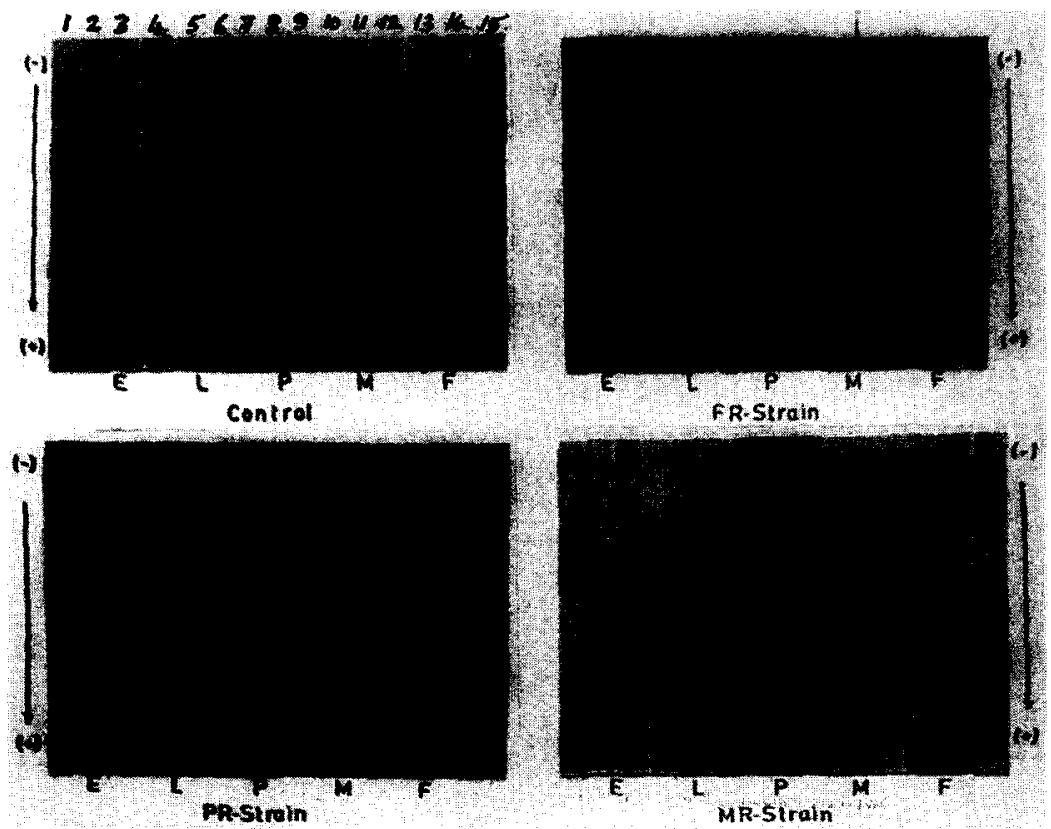

FIG. 3. Nonspecific esterases isozymes during different developmental stages for control (susceptible) and resistant strains for fenthion (FR), methyl parathion (PR) and malathion (MR) in An. stephensi. Life cycle stages: $E=$ eggs (channel 1-3), L = individual third instar larva (channel 4-6), $P=$ individual pupa (channel 7-9), $M=$ individual adult male (channel 10-12) and $F=$ individual adult female (channel 13-15). In all the strains, eggs showed one esterase band, whereas larvae showed several specific bands almost half the bands disappear at pupal stage. The adults showed difference in intensity and mobility of bands, exhibiting sexual dimorphism. 

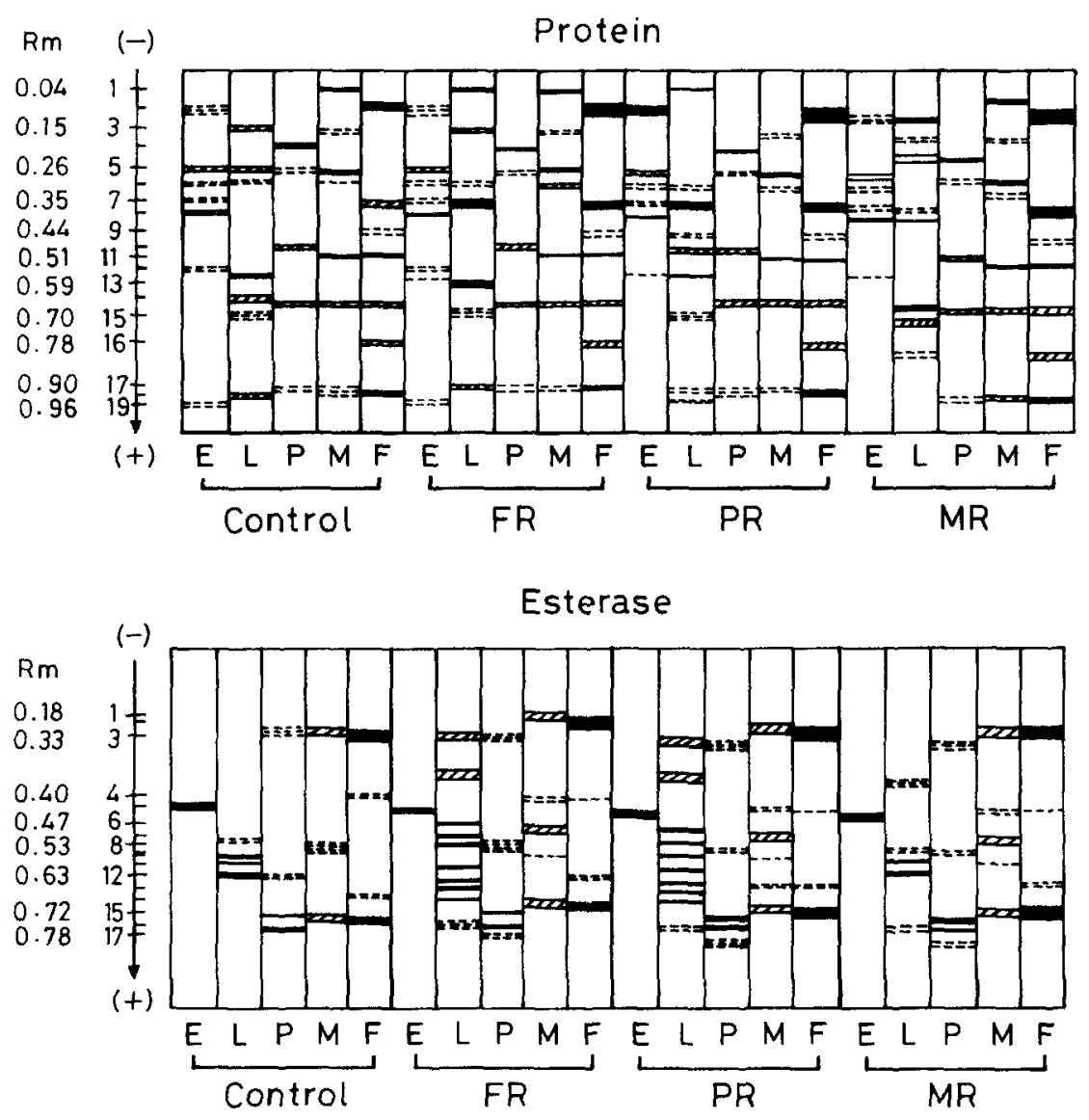

A

Ru values

\begin{tabular}{lcccccccccccccccccccccc}
\hline Band & 1 & 2 & 3 & 4 & 5 & 6 & 7 & 8 & 9 & 10 & 11 & 12 & 13 & 14 & 15 & 16 & 17 & 18 & 19 & \\
\hline Protein & 0.04 & 0.10 & 0.15 & 0.20 & 0.26 & 0.30 & 0.35 & 0.40 & 0.44 & 0.49 & 0.51 & 0.56 & 0.59 & 0.65 & 0.70 & 0.78 & 0.90 & 0.93 & 0.96 \\
$\begin{array}{l}\text { Esterase } \\
\text { isozyme }\end{array}$ & 0.18 & 0.22 & 0.33 & 0.40 & 0.44 & 0.47 & 0.51 & 0.53 & 0.55 & 0.58 & 0.59 & 0.63 & 0.66 & 0.68 & 0.72 & 0.74 & 0.78 & - & - & & &
\end{tabular}

$\mathbf{B}$

FIG. 4. Schematic presentation of proteins and esterase zymograms of the susceptible (control) and the resistant strains for fenthion (FR), methyl parathion (PR) and malathion (MR) in An. stephensi $(E=$ Eggs $L=L a r v a($ third instar) $P=P u p a ~ M$ $=$ Male (adult) $F=$ Female (adult). Relative intensities of bands are indicated by shading. Rm $=$ Relative mobility.

ever, $R_{m}$ values of $0.40,0.44,0.51,0.59$, and 0.78 of protein bands $(8,9,11,13$ and 16$)$, coincide with esterase bands $(4,5,7,11$, and 17$)$ respectively.

\section{DISCUSSION}

The quantity of total proteins among the resistant strains (FR, PR, and MR) was found to be higher as compared to the control, during different stages of development. The eggs as well as third instar larvae showed maximum protein content, which declined in the pupal stage. The changes in protein content during metamorphosis reflects specific differences in protein synthesis, release and uptake during pu- pation. The adult females showed higher protein content than males which may be related to specific protein for egg production (15).

Anong the resistant strains, eggs showed maximum protein bands few specific larval bands; most anodal bands disappeared upon pupation and certain bands reappeared during adult stage. Several specific protein bands for the resistant strains include two in eggs (13 and 19) for FR strain four in larvae $(9,10,12$, and 18$)$ in PR strain and four in larvae $(2,4,8$, and 16$)$ in MR strain.

In the resistant strains, the eggs showed only one esterase band, whereas larvae showed maximum bands. Almost half the bands disappeared at pupal stage. The adults showed 
difference in intensity and mobility exhibiting sexual dimorphism.

The hydrolytic degradation of phosphates is both qualitatively and quantitatively the most important detoxification reaction in insects. The insecticidal activity of a phosphate is a function of the ratio of quantity of insecticide taken up to the amount hydrolysed in a given period of time (2). The effect of malathion on the activity of detoxifying carboxylesterase has shown to be a major pathway for the degradation of organosphosphates in insects. Whereas other OP. insecticides including fenthion and methyl parathion induce resistance due to phosphate detoxification (12).

The toxicity of insecticides in mosquitoes is affected by numerous parameters including incomplete dominance to OP-insecticides like fenthion, methyl parathion and malathion $(5,6)$; variation in egg production and egg hatchability (4); the time of application (18); efficacy of cellular detoxification enzymes (12) environmental factors (3) and gene-amplification of detoxifying esterases (13). However, the toxicity and fate of OP-insecticides reflecting cellular detoxification mechanism require further investigation.

This is the first report of electrophoretic study of proteins and esterases in OP-insecticide resistant and susceptible strains, especially to fenthion, methyl parathion and malathion, in An. stephensi.

This work was supported by the grants from the University Grants Commission, Departmental Special Assistance, New Delhi, Irulia.

\section{References}

1. Davis, B.J. Disc electrophoresis II: Methods and application to human serum proteins. Ann. N.Y. Acad. Sci. 121:404-427; 1964.

2. Fest, C.; Schmidt, K.J. Organophosphorus insecticides. Buchel K.H., (ed), New York: Wiley Interscience; 93.

3. Fischer, S.W. Changes in the toxicity of three pesticides as a function of environmental $\mathrm{pH}$ and temperature. Bull. Environ. Contam. Toxicol. 46:197-202;1991.

4. Gangadhar Rao, D.E; Shetty, N.J. Effect of insecticide resistance on reproductive potential in Anopheles stephensi Liston, a malaria mosquito. Int. J.Toxicol. Occup. Environ. Hlth. 1: 48-52;1992.

5. Gangadhar Rao, D.E. Genetical, toxicological and biochemical studics on insecticide resistance of fenthion, methyl parathion and malathion in malaria mosquito, Anopheles stephensi Liston. Ph.D. Thesis, Bangalore University, Bangalore, India; 1993.
6. Gangadhar Rao, D.E.; Shetty, N.J. Genetic study of malathion resistance in Anopheles stephensi. J. Cytol. Genet. 29:215-219; 1994.

7. Georghiou, G.P.; Pasteur, N. Organophosphate resistance and esterase pattern in natural population of the southern house mosquito in California. J. Econ. Entomol. 73:489-492;1980.

8. Lee, H.L. Esterase activity and temephos susceptibility in Aedes aegypti (L) larvae. Mosquito Bourne Diseases Bull. 8: 91-94;1991.

9. Lines, J.D.; Ffrench-Constant, R.H.; Kasim, S.H. Testing Anopheles albimanus for genetic linkage of insecticide resistance genes by combining insecticide bioassay and biochemical methods. Med. Vet. Entomol. 4:445-450;1990.

10. Lowry, O.H.; Rosebrough, N.J.; Farr, A.L.; Randall, R.J. Protein measurement with Folin-Phenol reagent. J. Biol. Chem. 193:265-275;1951.

11. Maruyama, Y.; Yasutomi, K.; Ogita, Z.I. Electrophoretic analysis of esterase isozymes in organophosphate resistant mosquitoes (Culex pipiens). Insect. Biochem. 14:181-188;1984.

12. Matsumara, F. Toxicology of insecticides. New York: Plenum Press; 1985.

13. Mouches, G.; Pauplin, Y.; Agrawal, M.; Lemieux, L.; Herzog, M.; Abadon, M.; Beyssat-Arnaonty, V.; Hyrien, O.; DeSaint Vincent, B.R.; Georghiou, G.P.; Pasteur, N. Characterisation of amplification core and esterase $\mathrm{B} 1$ gene responsible for insecticide resistance in Culex. Proc. Natl. Acad. Sci. 87:25742578; 1990.

14. Pasteur, N.; Georghiou, G.P. Filter paper test for rapid determination of phenotypes with high esterase activity in organophosphate resistant mosquitoes. Mosq. News. 41:181-183; 1981.

15. Revanasiddaiah, H.M.; Chowdaiah, B.N. Electrophoretic studics on protcin changes during developmental stages of Anopheles stephensi. Ind. J. Med. Res. 75:40-44;1982.

16. Shetty, N.J.; Chowdaiah, B.N. Protein pattern of wild type and colour mutant larvae of Culex pipiens fatigans, a comparative electrophoretic study. Proc. Dunn. Dopzh. Symp. Genet. Mysore, India, 415; 1976.

17. Shidrawi, G.R. A World Health Organisation global programme for monitoring vector resistance to pesticides Bull Wld. Hlth. Org. 68:403-408;1990.

18. Szmedra, P.I. Pesticide use in agriculture. In: CRC Handbook of pest management in agriculture. (2nd ed.) Boston: CRC Press; 1991.

19. Whittaker, M.; Simpson, C.F. Electrophoretic techniques. Simpson, C.F.; Whittaker, M. (eds). London: Academic Press; 1983 ; p. 38.

20. World Health Organisation. Instructions for determining susceptibility or resistance of mosquito larvae to insecticides. Tech. Rep. Ser. 807; 1981.

21. World Health Organisation. Vector resistance to pesticides. Tech. Rep. Ser. 818; 1992. 